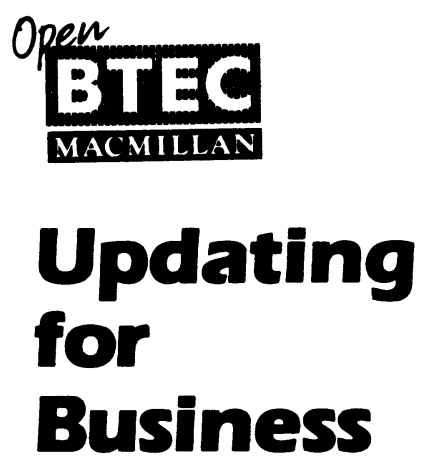

An MSC Open Tech sponsored project

\title{
Organising and Running Meetings
}

A Workbook designed for use with

Managing the Office, Element 9: Organising and Running Meetings 
Published by permission of the Controller of Her Majesty's Stationery Office.

This work was produced by the Business and Technician Education Council under an Open Tech contract with the Manpower Services Commission. The views expressed are those of the authors, and do not necessarily reflect those of the MSC, or any other Government Department.

All rights reserved. This publication is not part of the Copyright Licensing Scheme run by the Copyright Licensing Agency and may not be photocopied, or mechanically copied in any other way, without written permission from the publisher.

No paragraph of this publication may be reproduced, copied or transmitted save with written permission or in accordance with the provisions of the Copyright Act 1956 (as amended).

Any person who does an unauthorised act in relation to this publication may be liable to criminal prosecution and civil claims for damages.

First published 1986

Reprinted 1986, 1988

Published by

MACMILLAN EDUCATION LTD

Houndmills, Basingstoke, Hampshire RG21 2XS

and London

Companies and representatives throughout the world

ISBN 978-0-333-42579-4 ISBN 978-1-349-09026-6 (eBook)

DOI 10.1007/978-1-349-09026-6

\section{Managing the Office}

Unit Development Team

Leading Writer: Mike Verstage (Farnborough College of Technology)

Writers: Bill Edwards (NESCOT), Bea Hucker (Farnborough), Sue Smithson (Farnborough), Margaret Taylor (Kingston CFE), Janette Whitehead (Farnborough)

Educational Technologists: Maurice Benington, Diana Laurillard

Design Adviser: Mic Claridge (WSCAD, Farnham)

Managing Editor: Lynn Earnshaw

Materials Development Group: Ken Abraham (Slough CHE), Gerry Ashton (Royal Army Educational Corps), Alan Baikie (Johnson \& Johnson Ltd), Graham Carr (Farnborough College of Technology), Henry Goodman (BTEC) 


\section{Contents}

1 Introduction: The Trouble with Meetings

2 Why Have Meetings?

3 Formal and Informal Meetings and their Functions

5 Conduct of Meetings Procedure at a Meeting; Informal Procedures; Further Notes on Formal Procedures

6 Practical Preparation for a Meeting

7 Recording the Proceedings: The Minutes

Practical Guidance on Taking Notes at Meetings

8 Being a Chairperson Understanding How Groups Work; Qualities of a Competent Leader/Chairperson; Differences Between Leading an Informal Discussion and Chairing a Formal Meeting

9 Conclusion 


\section{Workbook Objectives}

After working through this Workbook you will be able to:

give reasons why meetings may be unproductive

list the different functions meetings perform

describe the differences between formal and informal meetings and give examples of each

describe the documents relating to formal meetings and the duties of the officers

explain the procedures used at a formal meeting for considering amendments to a motion and outline the steps a chairperson should take when dealing with a controversial matter at an informal meeting

prepare for a formal meeting

take minutes at a meeting

describe some of the types of role behaviour a chairperson will face at meetings, describe positive and negative qualities of each role and explain how to handle each type

Throughout this Workbook, you will see that each Activity is accompanied by a symbol.
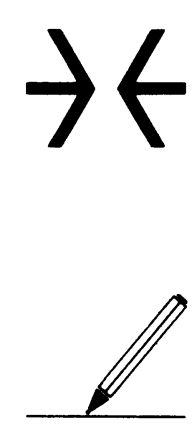

denotes reflective activity, in which you are asked to think for a few minutes about a particular subject, to focus on or reinforce what you have just been reading, and perhaps jot down some notes, before going on to the next piece of work.

denotes an activity for which a specific written answer is required, the answers to which you will find at the back of the book.

The times given are approximate, and for your guidance only.

If you are reading this Workbook as part of your study for the Open BTEC programme, the symbol which you should return to the Learning Sequence in the

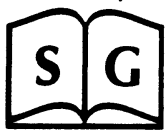
indicates points at accompanying Study Guide before proceeding. 